\title{
METIPRANOLOL-INDUCED ADVERSE REACTIONS: II. LOSS OF INTRAOCULAR PRESSURE CONTROL
}

\author{
TAYO AKINGBEHIN and JOSE R. VILLADA \\ Southport
}

\begin{abstract}
SUMMARY
This paper reviews the behaviour of intraocular pressure (IOP) in glaucomatous eyes treated with metipranolol with and without drug-induced adverse reactions (ADRs). Two hundred and forty seven patients with open angle glaucoma who were receiving the three different strengths of metipranolol $(0.1 \%, 0.3 \%$, and $0.6 \%)$ in our Department and the 7 patients who participated in the metipranolol rechallenge trial were included in this study. Out of the 247 patients, there were 52 eyes of 29 patients who showed 78 episodes of ADRs associated with metipranolol. Forty five of these 78 episodes $(57.6 \%)$ were associated with loss of IOP control. Two of the 7 eyes treated with metipranolol in the rechallenge trial showed loss of IOP control, 1 of them without any signs of ocular inflammation. We further studied all the glaucomatous eyes controlled with metipranolol $0.6 \%$ only and 22 eyes were identified with loss of IOP control but without recognisable signs or symptoms of ADR. Five other eyes in this group later developed metipranolol-induced ADRs. The possible pathophysiological mechanisms for the loss of IOP control are discussed and it is suggested that the active drug, metipranolol, could be directly implicated.
\end{abstract}

Elevation of intraocular pressure (IOP) is a well recognised complication of intraocular inflammation but its prevalence in the various inflammatory conditions as reported by several authors vary markedly. For example, the incidence of secondary glaucoma in patients with acute uveitis is quoted between $12 \%$ and $15 \%,{ }^{2}$ but in Fuch's Heterochromic Cyclitis estimates vary from $9 \%{ }^{3}$ to $59 \%$. $^{4}$ There is however, very little in the literature on the prevalence of secondary elevation of IOP in glaucomatous eyes with ocular inflammation.

We described in a previous paper ${ }^{5}$ the adverse reactions associated with the use of topical metipranolol in glaucomatous eyes i.e. granulomatous anterior uveitis, marginal keratitis, blepharoconjunctivitis and periorbital dermatitis. Some of these glaucomatous eyes with controlled IOP exhibited secondary elevation in IOP with the develop-

Correspondence to: Mr Tayo Akingbehin MD FRCS FCOphth, Department of Ophthalmology, District General Hospital, Southport, PR8 6NJ. ment of the metipranolol-induced adverse drug reactions (ADRs) which was not unexpected in those eyes with intraocular inflammation but was inexplicable in eyes with external ocular inflammation and those without any clinical signs of inflammation.

In this paper we continue our investigation of metipranolol-induced ADRs. We studied the behaviour of IOP in glaucomatous eyes with metipranolol-induced ADRs and also in those metipranolol treated eyes without clinical signs of ADRs.

\section{PATIENTS AND METHODS}

We reviewed retrospectively the case-notes of all patients treated with metipranolol in our department and examined those patients who responded to an invitation to attend special clinics as described in the previous paper. ${ }^{5}$ The behaviour of the IOP in the eyes of those patients entered into the rechallenge study were also analysed. ${ }^{6}$

In the light of the preliminary results of the above two studies we further reviewed the behaviour of IOP in all glaucomatous eyes who had been controlled with metipranolol $0.6 \%$ only.

\section{RESULTS}

Two hundred and forty seven glaucoma patients in our department were treated with guttae metipranolol: 109 with metipranolol $0.6 \%, 103$ with metipranolol $0.3 \%$ and 35 with metipranolol $0.1 \%$

Seven patients completed the metipranolol rechallenge study.

From case-notes and clinical reviews we found 29 patients (52 eyes) with metipranolol-induced ADRs: granulomatous anterior uveitis (15 patients, 25 eyes); blepharoconjunctivitis (11 patients, 21 eyes); combined granulomatous anterior uveitis and blepharoconjunctivitis ( 2 patients, 4 eyes); periorbital dermatitis (1 patient, 2 eyes); and marginal keratitis ( 1 patient, 2 eyes).

There was a total of 78 different recorded episodes of ADRs suffered by the 52 eyes of the 29 patients. In 45 episodes $(57.6 \%)$ there was a significant elevation in IOP $(\geqslant 5 \mathrm{~mm} \mathrm{Hg}$ ) associated with the ADR. The distribution of the patients, eyes and episodes in which there was loss 
Table I. Distribution of patients, eyes and episodes in which there was a loss of IOP control

\begin{tabular}{lccc}
\hline Reaction & No. of patients & Eyes involved & No. of episodes \\
\hline G A U & 10 & 17 & 27 \\
B C & 8 & 11 & 11 \\
B C \& G A U & 2 & 3 & 5 \\
M K & 1 & 2 & 2 \\
P D & 0 & 0 & 0 \\
& $20^{*}$ & 33 & 45 \\
\hline
\end{tabular}

*One patient is counted twice because she had different reactions in each eye.

G A U granulomatous anterior uveitis

B C blepharoconjunctivitis

M K marginal keratitis

P D periorbital dermatitis

of IOP control is shown Table I. In 42 out of the 45 (93.3\%) episodes of ADR with elevation of IOP the responsible drug was metipranolol $0.6 \%$ and in the remaining 3 episodes $(6.7 \%)$ metipranolol $0.3 \%$ was implicated (Table II).

The 27 episodes (out of a total of 46 episodes) of granulomatous anterior uveitis with loss of IOP control had a range of $\triangle \mathrm{IOP}$ from 8 to $32 \mathrm{~mm} \mathrm{Hg}$ with a mean $\triangle \mathrm{IOP}$ of $16.7 \mathrm{~mm} \mathrm{Hg}$ (SD 6.3). There were 11 episodes of blepharoconjunctivitis with loss of IOP control (11 out of 20 ), range of $\triangle$ IOP 5-18 mm Hg and mean $\triangle$ IOP 10.3 $\mathrm{mm} \mathrm{Hg}$ (SD 4.6) and 3 episodes of combined granulomatous anterior uveitis and blepharoconjunctivitis with significant elevation in IOP ( 3 out of 8$)$, had a range $\triangle$ IOP 8-22 $\mathrm{mm} \mathrm{Hg}$ and mean $\triangle$ IOP $11.6 \mathrm{~mm} \mathrm{Hg}$ (Table III).

Two metipranolol $0.3 \%$ treated eyes of the 7 patients in the rechallenge study showed an elevation of IOP within two weeks of the start of the study, 1 of them without any signs of ocular inflammation and a $\triangle$ IOP of $17 \mathrm{~mm} \mathrm{Hg}$. The other eye had granulomatous anterior uveitis, blepharoconjunctivitis, ectropion secondary to the skin changes and a $\triangle$ IOP $22 \mathrm{~mm} \mathrm{Hg}$.

The further review of patients and case-notes revealed 27 eyes of 14 patients on metipranolol $0.6 \%$ only with significant elevation in IOP $(\geqslant 5 \mathrm{~mm} \mathrm{Hg})$ prior to the development of any recognisable clinical features of ADRs. Five of these eyes later developed metipranololinduced granulomatous anterior uveitis within a few weeks. The other 22 eyes of 11 patients in this group were changed from metipranolol $0.6 \%$ to other anti-glaucoma

Table II. Distribution of episodes of ADRs associated with loss of IOP control and different strengths of metipranolol

\begin{tabular}{lccc}
\hline ADR & $\begin{array}{c}\text { metipranolol } \\
0.1 \%\end{array}$ & $\begin{array}{c}\text { metipranolol } \\
0.3 \%\end{array}$ & $\begin{array}{c}\text { metipranolol } \\
0.6 \%\end{array}$ \\
\hline G A U & 0 & 0 & 27 \\
B C & 0 & 1 & 10 \\
B C \& G A U & 0 & 0 & 5 \\
M K & 0 & 2 & 0 \\
P D & 0 & 0 & 0 \\
\hline & 0 & 3 & 42 \\
\hline
\end{tabular}

G A U granulomatous anterior uveitis

B C blepharoconjunctivitis

M K marginal keratitis

P D periorbital dermatitis medications (timolol maleate $0.5 \%, 10$ eyes; carteolol $2 \%$, 8 eyes; levobunolol $0.5 \%, 2$ eyes; pilocarpine $1 \% 2$ eyes) which controlled the IOP and were therefore not seen to develop any metipranolol-induced ADRs.

\section{DISCUSSION}

The incidence of secondary glaucoma in patients with acute uveitis in non-glaucomatous eyes in other studies varies between $12 \%$ (IOP $>21 \mathrm{~mm} \mathrm{Hg}$ on at least two occasions $)^{1}$ and $15 \%(\mathrm{IOP}>25 \mathrm{~mm} \mathrm{Hg}){ }^{2} \mathrm{Jones}^{7}$ review of glaucoma in 103 patients with Fuch's Heterochromic Cyclitis showed an incidence of $26.2 \%$ but other investigators have reported estimates which vary from $9 \%$ to $59 \%{ }^{4}$

This paper reviews the secondary elevation in IOP seen in eyes with primary glaucoma treated by metripranolol with or without the various forms of metipranolol-induced ADRs. As far as could be determined from the case notes, the 52 eyes of the 29 patients who developed metipranolol-induced ADRs had controlled IOPs i e. $<22 \mathrm{~mm} \mathrm{Hg}$ prior to the first documentation of an ADR. Where an eye suffered more than one episode of ADR (as there were a total of 78 episodes in this group) the IOP returned to within normal limits on the same anti-glaucoma treatment before the development of subsequent ADRs. In this group of glaucomatous eyes therefore, further elevation in IOP was only seen with an active ADR.

In this study, loss of IOP control or significant elevation in IOP is taken as an increase in IOP greater than $5 \mathrm{~mm}$ $\mathrm{Hg}$.

The incidence of loss of IOP control was similar in the three sub-groups of ADRs: granulomatous anterior uveitis $59 \%$, blepharoconjunctivitis $60 \%$ and granulomatous anterior uveitis and blepharoconjunctivitis combined $62.5 \%$. In the sub-group with marginal keratitis the 2 eyes affected showed this phenomenon (100\%) but the number is too small for any meaningful conclusion. The 2 glaucomatous eyes with metipranolol-induced periorbital dermatitis did not show any loss of IOP control.

Panek ${ }^{1}$ listed several pathophysiological mechanisms for the elevation of IOP in eyes with uveitis:

Table III. Elevation of IOP in the different metipranolol-associated adverse reactions

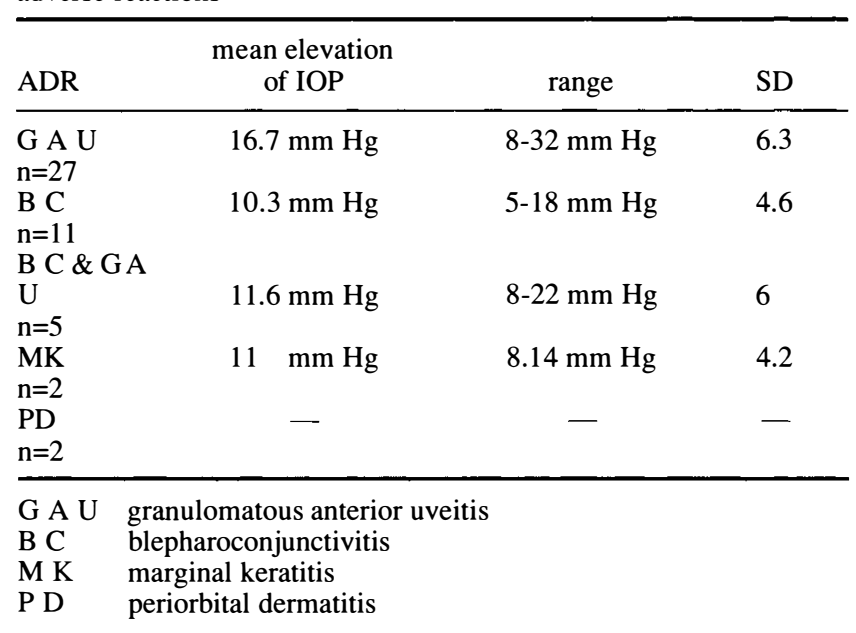


(1) mechanical blockage of the trabeculum by serum components that are liberated because of vascular incompetence;

(2) hypersecretion associated with prostaglandin mediated vascular hyperpermeability;

(3) overtaxing of outflow mechanisms by protein that interferes with active transport;

(4) inflammation of the trabeculum itself with swelling which causes impaired outflow;

(5) damage to trabecular endothelial cells by the inflammatory process;

(6) mechanical obstruction of outflow by precipitates on the meshwork;

(7) sclerosis of trabecular meshwork as a result of chronic inflammation; or

(8) obstruction of the trabeculum by a hyaline membrane All of these mechanisms are probably enhanced in eyes with primary open-angle glaucoma where the function of the trabecular meshwork is already compromised.

The five sub-groups of metipranolol-induced ADRs represent three different forms of ocular inflammation. The granulomatous anterior uveitis and the combined granulomatous anterior uveitis and blepharoconjunctivitis sub-groups both show signs of intraocular inflammation which can be associated with elevation in IOP in $12-15 \%$ of normal eyes, ${ }^{2,3}$ but in our study the prevalence was $59 \%$ and $62.5 \%$ respectively in the two sub-groups of glaucomatous eyes with ADRs which is significantly higher. Kinshuck $^{8}$ reported an elevation in IOP in 13 out of his 16 glaucomatous eyes $(87 \%)$ with metipranolol-associated granulomatous anterior uveitis.

The two sub-groups of external ocular inflammation, i.e. blepharoconjunctivitis and marginal keratitis, are not often associated with secondary elevation in IOP unless the external inflammation is so severe as to be accompanied by decompensation of the blood-aqueous barrier. In this study the prevalence of secondary elevation in IOP was $60 \%$ and $100 \%$ respectively in the two sub-groups. We were unable to find any figures in the literature for the prevalence of secondary glaucoma in normal or glaucomatous eyes with external ocular inflammation but the figures obtained in our study are considerably higher than would have been expected. The case of periocular dermatitis represents inflammation of the adnexal structures and would not have been expected to demonstrate a change in IOP.

It is difficult to postulate a single mechanism of action for the elevation in IOP seen in the different forms of metipranolol-induced inflammations without implicating the active drug, i.e. metipranolol. If this was the case, then, one would expect a number of eyes on metipranolol with loss of IOP control and no clinical signs of ADRs. Indeed, there were 27 eyes of 14 patients out of 109 patients receiving metipranolol $0.6 \%$ in which this was observed, 22 of these eyes had no sign of ADR when the metipranolol $0.6 \%$ was changed to other ophthalmic topical medications because of loss of IOP control. However, there is a possibility that the loss of IOP control was due to pro- gression of the glaucoma and not related to the use of metipranolol. The trend of elevation in IOP was not gradual as would be expected for worsening of glaucoma and also the fact that IOP control was achieved very quickly with a comparable or less efficacious anti-glaucoma therapy, both support the view that the loss of IOP control might be related to metipranolol. The IOPs in these eyes have remained within normal limits without additional antiglaucoma therapy for two years.

The mean elevation in IOP was highest in the uveitic sub-group ie $16.7 \mathrm{~mm} \mathrm{Hg}$. These eyes were managed in different ways but unfortunately the number of eyes in each treatment group is too small for any objective conclusions. All the eyes showed return of IOP to within normal range except in one eye which had pseudoexfoliative glaucoma and finally required filtration surgery.

The exact mechanism of the secondary elevation of IOP is unknown but probably associated with some changes in the trabecular meshwork caused by the active drug, metipranolol, itself. There were no additional findings in the iridocorneal recess on gonioscopic examination. Also there were no significant differences in age, sex, time since glaucoma was first diagnosed, period on metipranolol, associated diseases or other medications which may indicate any predisposition for the decompensation of trabecular function with further reduction in outflow facility and consequently the loss of IOP control. The rather quick recovery of IOP control in these eyes, both those with and those without metipranolol-induced ADRs, when metipranolol was discontinued suggest that the secondary elevation in IOP was not due to progression of the disease. The behaviour of the IOP in these metipranolol treated eyes is not similar to that experienced with long term use of timolol (the 'long-term drift') which has been described by other authors. ${ }^{9,10}$ Also, this phenomenon of loss of IOP control has been observed after a very short period of metipranolol treatment, for example, the 2 eyes in the rechallenge study with marked elevation in IOP within two weeks of treatment with metipranolol $0.3 \%$ This evidence is against progression of the disease or loss of drug efficacy as the cause of the secondary elevation in IOP in these metipranolol treated eyes.

In conclusion, this study reveals a high incidence of secondary elevation in IOP in glaucomatous eyes treated with metipranolol $0.3 \%$ and $0.6 \%$ The intraocular inflammatory ADRs associated with metipranolol could compromise further the reduced outflow facility of these glaucomatous eyes but this is not a plausible explanation for the loss of IOP control in all the different types of ADRs, and in particular, for those eyes without clinical signs or symptoms of ADRs. It is suggested that the active drug, metipranolol, is implicated directly in the pathophysiology of this secondary elevation in IOP.

\section{REFERENCES}

1. Panek WC, Holland GN, Lee DA, Christensen RE. Glaucoma in patients with uveitis. Br J Ophthalmol 1990, 74: 223-7.

2. Rothora A, Van Veenendaal WG, Linssen A, Galsius E, Kijlstra A, De Jong PTVM. Clinical features of acute anterior uveitis. Am J Ophthalmol 1987, 103: 137-45. 
3. Jain IS, Gupta A, Gangwar DN, Dhir SP. Fuchs' heterochromic cyclitis: some observations on clinical picture and on cataract surgery. Ann Ophthalmol 1983, 15: 640-2.

4. Liesegang TJ. Clinical features and prognosis in Fuchs' uveitis syndrome. Arch Ophthalmol 1982, 100: 1622-6.

5. Akingbehin T and Villada JR. Metipranolol-associated granulomatous anterior uveitis. Br J Ophthalmol 1991, 75: 519-23.

6. Akingbehin T, Villada JR, Walley T. Metipranolol-induced adverse reactions: I. The rechallenge study. Eye 1992, 6: 277-79.
7. Jones NP. Glaucoma in Fuchs' heterochromic uveitis: aetiology, management and outcome. Eye 1991, 5: 662-7.

8. Kinshuck D. Glauline (metipranolol) induced uveitis and increase in intraocular pressure. Br J Ophthalmol 1991, 75: 575.

9. Boger WP. Timolol short-term 'escape' and long-term 'drift'. Ann Ophthalmol 1979, 11: 1239-41.

10. Mills KB. Blind randomized non-crossover long-term trial comparing topical timolol $0.25 \%$ with $0.5 \%$ in the treatment of chronic simple glaucoma. Br J Ophthalmol 1981, 67: 216-19. 